\title{
Delineation of Hydrothermally Altered Zones that Favour Gold Mineralization in Isanlu Area, Nigeria Using Aeroradiometric Data
}

\author{
Ohioma Jerry O. ${ }^{1 *}$, Ezomo Friday O. ${ }^{2}$, Akinsunmade A. ${ }^{3}$ \\ ${ }^{1}$ Department of Physics, University of Benin, Benin City, Edo State, Nigeria \\ ${ }^{2}$ Department of Physics, University of Benin, Benin City, Edo State, Nigeria \\ ${ }^{3}$ Nigerian Geological Survey Agency, Benin City, Edo State, Nigeria
}

\section{ABSTRACT}

Aeroradiometric data set of Isanlu sheet $225(1: 100,000)$ has been acquired with a view to analyze and interpret for the delineation of hydrothermally altered zones that favour gold mineralization. The acquired aero-radiometric data was subjected to filtering algorithm and enhancement techniques such as shaded relief enhancement, elemental ratio enhancement using Geosoft Oasis Montaj Software. Moreover, Golden Software Surfer was used to identify and present the revealed hydrothermally altered zones. The interpretation of the aero data set has enhanced the delineation of eight hydrothermally altered zones. Therefore, the areas that are hydrothermally altered are potential sites for gold mineralization, such as areas around Odogbe and Okolom in the north-central portion of the study area. Similarly, regions around Egbe in the western edge are suspected to be mineralized zones. Results obtained in this research study have shown that mapping of hydrothermally altered zones that favour gold mineralization is feasible even without the actual physical contact and visitation to the area. The research suggests that this method of delineation may compliment other geophysical exploration technique for possible gold bearing zones of an area. Moreover, due to the non-invasive nature of the method, large areas of space may be mapped within a limited time. Areas that are nonaccessible to ground geophysical exploration due to various factors can also be studied.

Keywords: Aeroradiometric Data; Gold Mineralisation; Hydrothermal Alteration; Isanlu Sheet 225 .

\section{Introduction}

The Nigerian mining sector has recently witnessed higher levels of activity following reform programs that have been undertaken in areas of policy, institutions and the legal frame work that are intended to bring Nigeria in line with global best practice.

* Corresponding author email: ohioma.jerry.ohi@gmail.com DOI : https://doi.org/10.21467/ias.2.1.20-27
The quest for more natural resources occurrences and the diversification policy of the economy from over dependency on oil and gas by the Nigerian government have informed the choice of this research study. Attempt have been made to delineate the hydrothermally altered zones that may culminate into the emplacement of gold mineralisation around Isanlu area, Yagba west local government, Kogi state, North Central Nigeria. 
Ohioma et al., Int. Ann. Sci.; Vol. 2 Issue 1, pp: 20-27, April 2017

Hydrothermal mineral deposits are those in which hot water serves as a concentrating, transporting and depositing agent through faults (structures) to the earth's surface. Hydrothermal mineral deposit any concentration of metallic minerals formed by the precipitation of solids from hot mineral-laden water (hydrothermal solution). The solutions are thought to arise in most cases from the action of deeply circulating water heated by magma. Other sources of heating that may be involved include energy released by radioactive decay or by faulting of the Earth's crust. These waters may deposit their dissolved minerals in openings in the rock, thus filling the cavities, or they may replace the rocks themselves to form so-called replacement deposits. Both processes may occur simultaneously, the filling of an opening by precipitation accompanying the replacement of the walls of the opening. Deposition can be caused by boiling, by a drop in temperature, by mixing with a cooler solution or by chemical reactions between the solution and a reactive rock. Hydrothermal deposits are never formed from pure water, because pure water is a poor solvent of most ore minerals. Rather, they are formed by hot brines (water containing salts), making it more suitable to refer to them as products of hydrothermal solutions. Brines and especially sodium-calcium chloride brines are effective solvents of many sulfide and oxide ore minerals and they are even capable of dissolving and transporting native metals such as gold and silver. The water in a hydrothermal solution can come from any of several sources. It may be released by a crystallizing magma; it can be expelled from a mass of rock undergoing metamorphism; or it may originate at Earth's surface as rainwater or seawater and then trickle down to great depths through fractures and porous rocks, where it will be heated, react with adjacent rocks and become a hydrothermal solution. Irrespective of the origin and initial composition of the water, the final compositions of all hydrothermal solutions tend to converge, owing to reactions between solutions and the rocks they encounter. Most gold deposits are sourced from metamorphic rocks because it is thought that the majority are formed by dehydration of basalt (mafic rock) during metamorphism.
The regional setting in Nigeria is very similar to the Ashanti and Sefwi systems in nearby Ghana, with gold being found in most parts of supracrustal (Schist) belts in the northwest and southwest. Though the precious metals are not essential for industrialisation, they are a high source of foreign exchange and their exploitation to a large scale promotes the establishment of ancillary industries.

Regionally, primary gold deposits are associated with some Schist belts of northwest and southwest Nigeria (e.g. Isanlu, Maru, Anka, Kushaka) but not with others (e.g. Wonaka, Karaukarau, IseyinOgun River) and each covers several thousand square kilometers [1]. In order to explore for various natural potentials within the Nigeria landmass, there is need to develop a roadmap to investigate the various zones that might host valuable minerals such as gold within the country. With the objective to delineate the hydrothermally altered zones of sheet 225 (Isanlu); part of the Schist belt of Nigeria, this study attempts to use aeroradiometric data to delineate the various zones that favour hydrothermal gold mineralization in the area. Aero-survey measurements are usually made from low-flying airplanes flying along closely spaced, parallel flight lines. Additional flight lines are flown in the perpendicular direction to assist in data processing. These large volumes of measurements then are processed into a digital aerodata map. Aeroradiometric survey is one of the most important tools used in modern geological mapping and mineral exploration. The principle is similar to radiometric survey carried out with a hand-held spectrometer but enables larger areas of the Earth's surface to be covered quickly for regional reconnaissance; this is needed because most of the Schist belts in which gold is found in Nigeria cover several thousand square kilometres. The aircraft typically flies in a grid-like pattern with height and line spacing determining the resolution of the data (and cost of the survey per unit area). This survey along a profile or grid determines the strength of the radiometric fields at particular points by measuring spatial variations in the Earth's radiometric field [2].

It involves the measurement of naturally occurring uranium (U), thorium (Th) and potassium (K), 
which could be found as trace elements that exist in rock forming minerals and soil profiles. In radiometric survey, the gamma ray response from the radioelements $(\mathrm{K}, \mathrm{U}$ and $\mathrm{Th})$ in the rocks can be related to the hydrothermal alterations in the area.

\section{Location and Geological Setting of the Study Area.}

The study area is located within $8^{0} 00^{\prime} 00^{\prime \prime} \mathrm{N}$ to 8030’00”N and 5030’00”E to 6000'00”E (Isanlu Sheet 225). The geology of Nigeria is made up of three main rock groups: Precambrian Basement Complex, Younger Granites and Sedimentary Basins [3]. The study area is a part of the Schist belt of the Precambrian Basement Complex of North Central Nigeria as shown in Figure 1. The Schist Belts comprise low grade, meta-sedimentdominated belts which are best developed in the western half of Nigeria. These belts are considered to be Upper Proterozoic supracrustal rocks which have been infolded into the migmatite-gneissquartzite complex. Most metallogenetic features of the Schist belts are relevant to these problems; the apparent absence of subduction related mineral deposits; the distribution of primary gold occurrences in some belts but its marked absence in others may indicate that they do not represent a single supracrustal sequence.

\section{Methodology}

The aeroradiometric data analysed for this study was obtained from Nigerian Geological Survey Agency. The data are part of the nationwide aero geophysical survey programme sponsored by the Nigerian geological survey agency. The data acquisition was carried out by fixed wing aircraft. Total line kilometers of 36,500 were covered in the survey. Multi-channel radiometric was the measured parameter. The data were acquired along a series of NW-SE flight lines with a spacing of 500 meters and an average flight elevation of about 100 metres while tie lines occur at about 2000 metres interval in the NE-SW direction. The data were made available in the form of grid on a scale of 1:100,000.

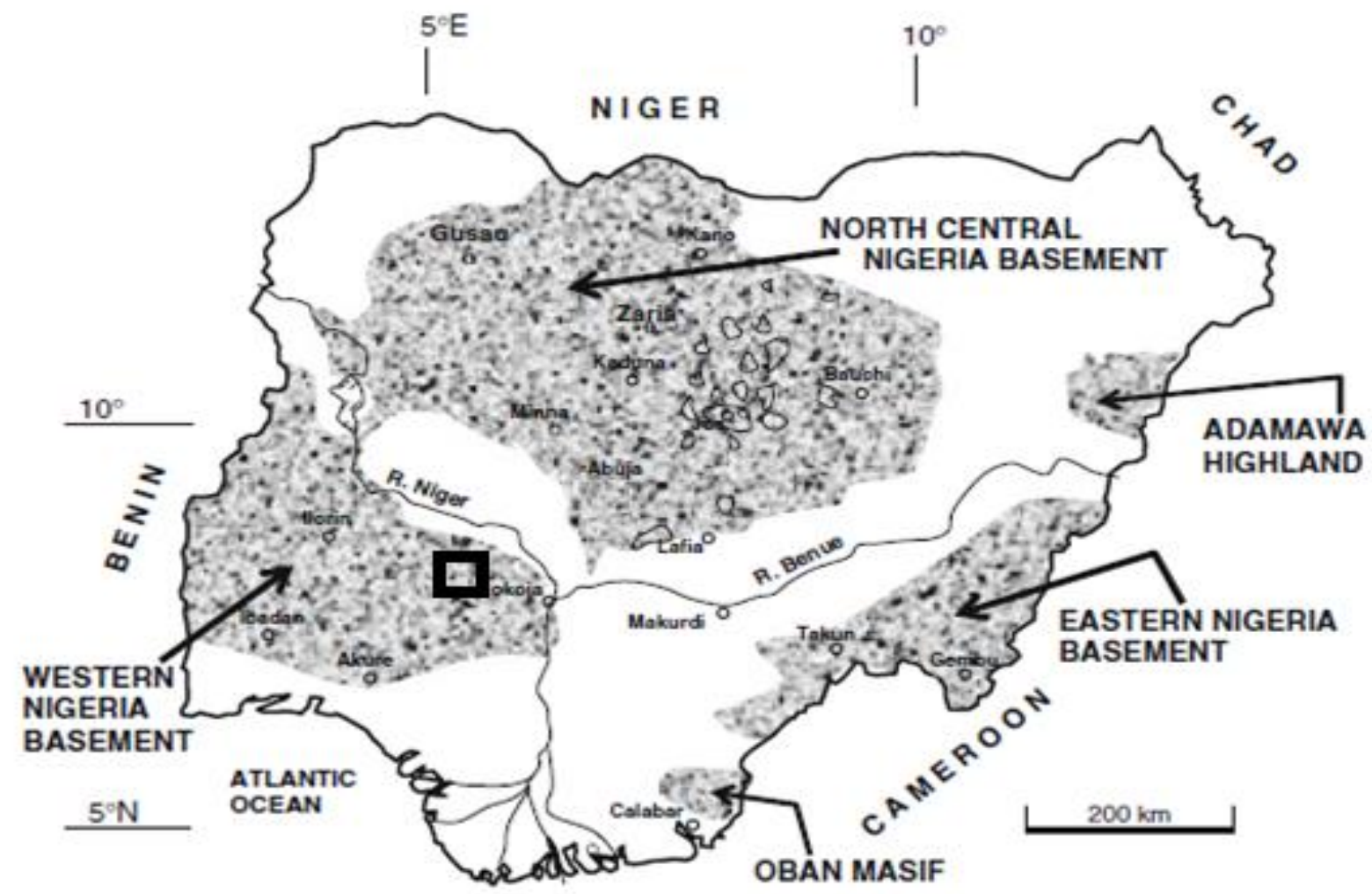

Study Area

Figure 1: Basement geological map of Nigeria [4] 
Ohioma et al., Int. Ann. Sci.; Vol. 2 Issue 1, pp: 20-27, April 2017

The aircraft had a gamma ray spectrometer mounted on its fixed wings. The radiometric data were sampled at a rate of $1 \mathrm{sec}$, using the Exploranium GR-820 modern spectrometer system. Geophysical processing consisted of gridding spectrometric airborne survey data using a variety of software. The major software used to process and enhance the data is the Geosoft (Oasis Montaj). Other geophysical software was used to enhance the data in a variety of formats such as Golden Software Surfer 10.

\section{$4 \quad$ Results and Discussion}

Airborne gamma-ray spectrometric data are often used as a powerful tool to aid mineral exploration. This is achieved by visual inspection of the map.

\subsection{Ratio Map}

Abundance ratio of $\mathrm{Th} / \mathrm{K}$, are often more diagnostic of alteration or depositional environment than the values of the radio-isotope abundances themselves, which are subject to wide variations due to soil cover, etc. The effect of environmental factors on radiometric response, such as soil moisture, vegetation and topography, are less evident on band ratios. Also, since there is usually a high correlation between bands, the ratios often show subtle features that are not apparent on the original grids. The ratio map used in this project is the $\mathrm{Th} / \mathrm{K}$ and this map have been used to show zones within the study area that are hydrothermally altered, since hydrothermal alterations normally lead to the enrichment of one radioactive element at the expense of the other [5][6]. In general, thorium (Th) is not affected by alteration processes due to the fact that $\mathrm{Th}$ is typically immobile in mineralisation processes or it can only partly be depleted in areas of intense $\mathrm{K}$-alteration and silicification. The $\mathrm{Th} / \mathrm{K}$ ratio is therefore a better indicator of hydrothermal alteration than any single radioelement alone. In many gold deposits, Th has been mobilised and depleted with the simultaneous increase of $\mathrm{K}$ [7][8][9]. Figure 2 represents $\mathrm{Th} / \mathrm{K}$ (reverse $\mathrm{K} / \mathrm{Th}$ ) concentrations which map enhanced alteration signatures. The $\mathrm{Th} / \mathrm{K}$ ratio map shows that high content of the Thorium in the red color implies weak content of Potassium and vice versa for the blue colour.

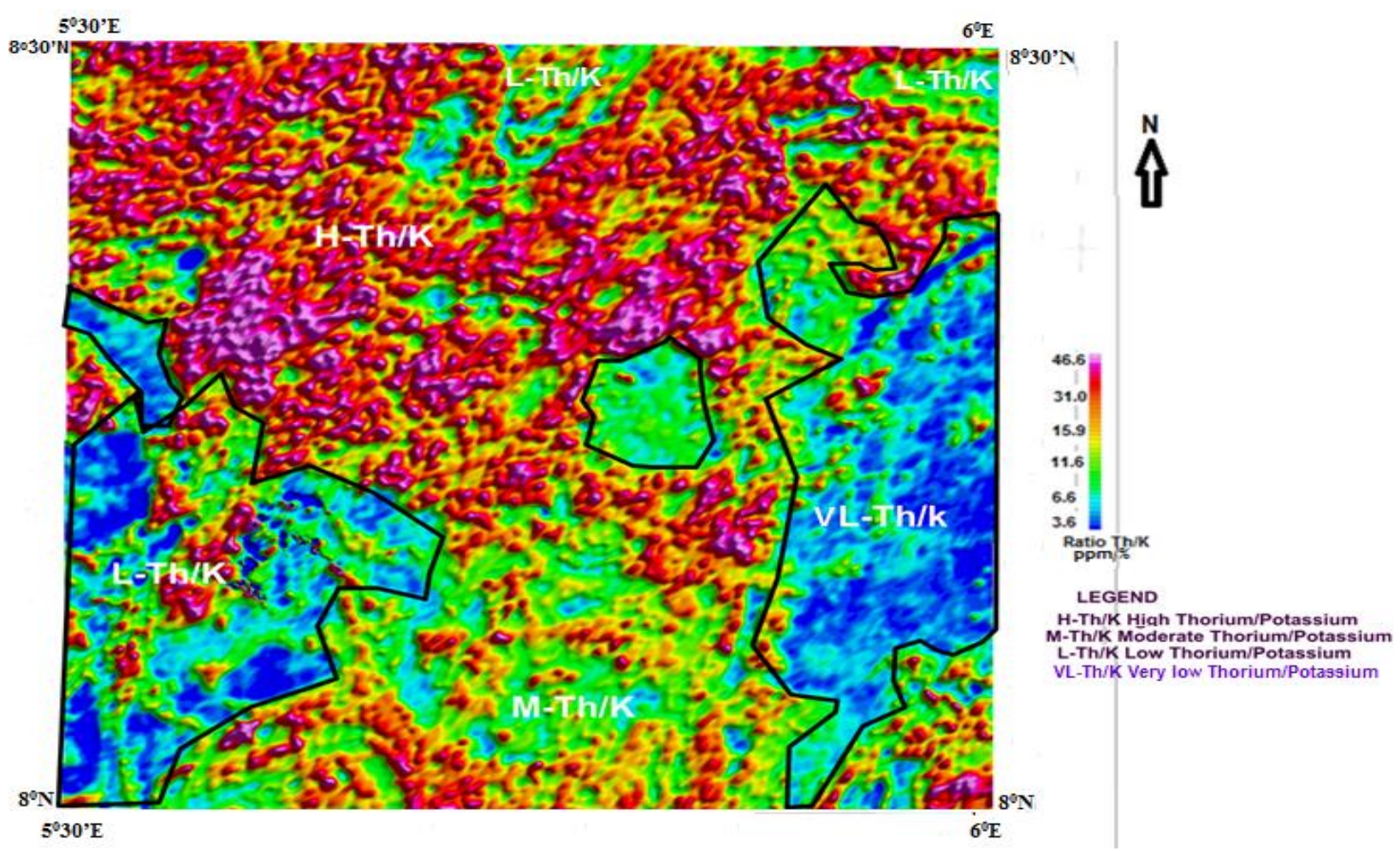

Figure 2: Radiometric Thorium-Potassium Ratio Map of Isanlu Sheet 225 
The reduction in $\mathrm{Th} / \mathrm{K}$ ratio observed in the $\mathrm{L}$ $\mathrm{Th} / \mathrm{K}$ regions is indicative of hydrothermal alteration. This is because $\mathrm{K}$ enrichments are not accompanied by Th during hydrothermal alteration processes [7]. A number of mineralisation of gold districts demonstrates an enhancement in potassium and depletion of thorium like in the north-western areas which implies that thorium was mobilized during the hydrothermal activities. This information led to the detection of hydrothermal alteration zones within the area. Generally, just $\mathrm{K}$ and other metal constituents are added to host rock by hydrothermal solutions and it is easily observed along lithological contacts where the hydrothermal alteration is intensive.

\subsection{Ternary Map}

The Ternary image consists of colors produced from the individual concentrations of the gamma radiations and corresponds to slight differences in the relative amounts of the three components.

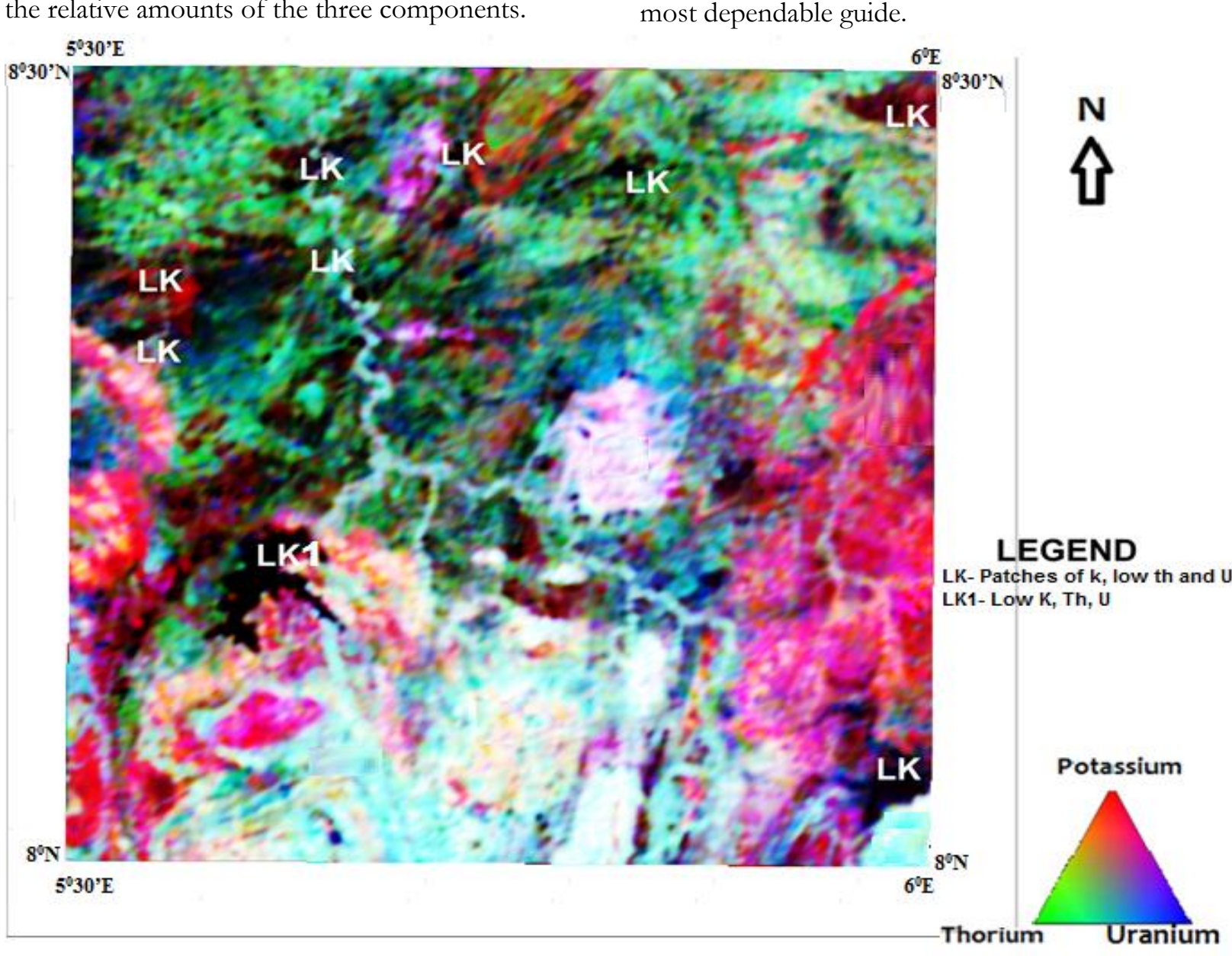

Figure 3 is a ternary map of all the three radioactive elements and the colours are interpreted as follows;

$>$ Red indicates high potassium with low uranium and thorium

$>$ Blue indicates high uranium with low potassium and thorium

$>$ Green indicates high thorium with low potassium and uranium

$>$ Cyan indicates high thorium and uranium with low potassium

$>$ Magenta indicates high potassium and uranium with low thorium

$>$ Yellow indicates high potassium and thorium with low uranium

$>$ Black indicates low potassium, thorium and uranium

$>$ White indicates high potassium, thorium and uranium.

It was noticed by Hoover \& Pierce [9] that airborne gamma-ray surveying marks of deposits of gold were changeable with potassium being the most dependable guide.

Figure 3: Radiometric Ternary Map of Isanlu Sheet 225 
Ohioma et al., Int. Ann. Sci.; Vol. 2 Issue 1, pp: 20-27, April 2017

Regions with the gold within quartz veins, hydrothermal alteration of causative body can provide noticeable way out. Despite the fact that there is no unique radiometric pathway for deposits of gold, research conducted by Hoover \& Pierce [9] depicts that transforms in the all three radioisotopes can happen and could be identified in airborne radiometric prospecting. Using the colour scheme, the following interpretations were made from the ternary map as shown in Figure 3. The LK1 region shows darker than the neighboring formations, indicating very weak contents in potassium, uranium and thorium which indicate that hydrothermal alteration may not have occurred in this zone. LK regions have recorded very low concentration of uranium and thorium having patches of potassium which coincides with the low $\mathrm{Th} / \mathrm{K}$ seen in the L-Th/K region of the $\mathrm{Th} / \mathrm{K}$ ratio map (Figure 2 ). It is also seen that the region $\mathrm{LK}$ is observed to have an enrichment of higher concentration of potassium compared to the other elements. The enrichment of potassium relative to the other elements especially thorium is an indication of hydrothermal alteration. And because LK has higher potassium activity compared to the other elements, it means LK has been altered hydrothermally. These regions represent the hydrothermal alteration zones that may be favorable for gold mineralisation.

\section{Projected Map of the Hydrothermally Altered Zones that Favour Gold Mineralisation from Airborne Radiometric Data}

Gold mineralisation in the Schist belts of Nigeria and particularly the present study area is associated with tectonic events that promote rock alteration. Rock alteration could be due to structural deformation or chemical reaction [10]. It has been suggested that tectonometamorphic processes controlled the origin of Isanlu-Egbe primary gold mineralisation. This involved the heating up and pushing the mineralizing fluid through the basic volcanics and sediments under tectonometamorphic conditions.

\section{ISANLU}

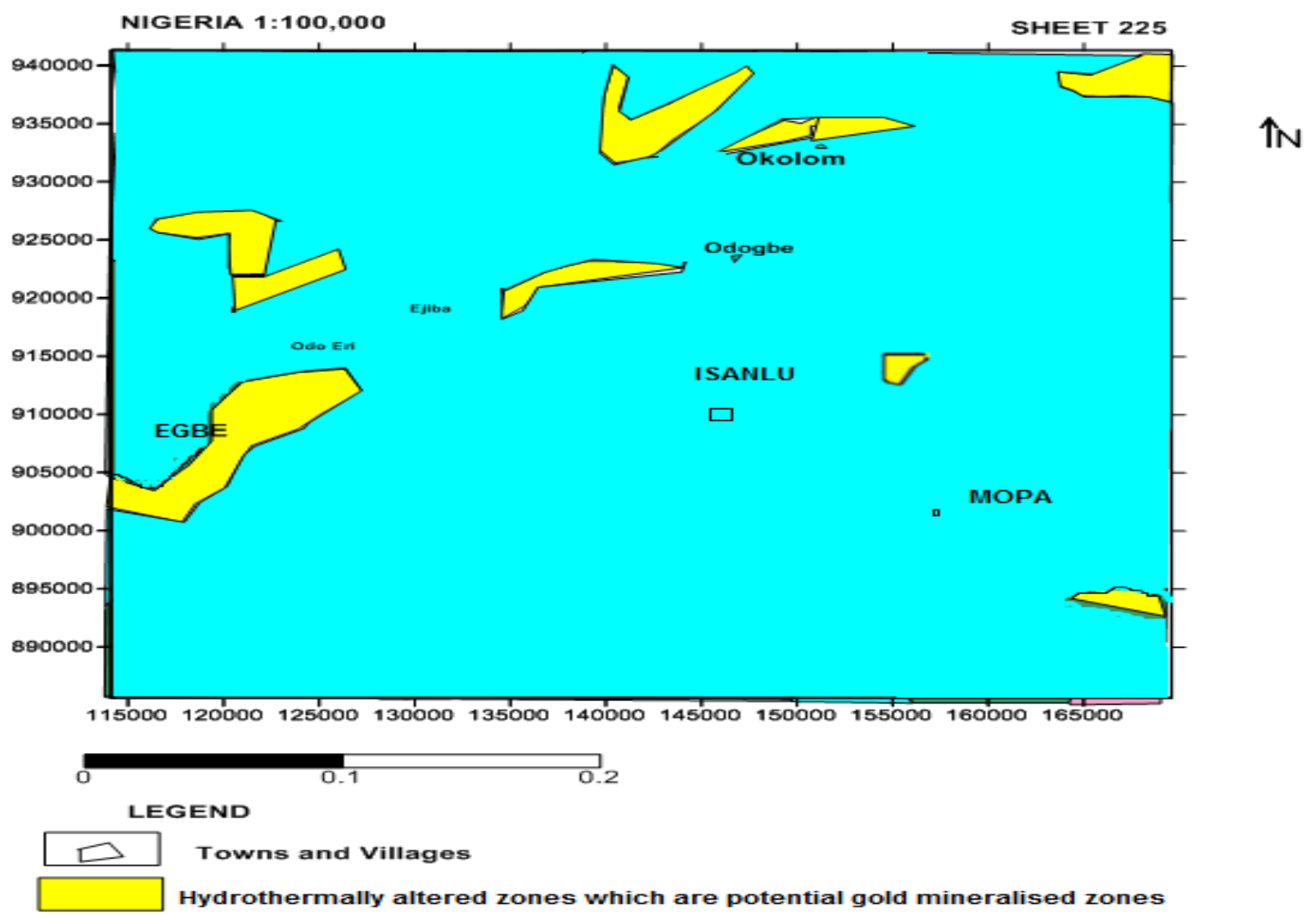

Figure 4: Interpreted Map Showing the Hydrothermally Altered Zones from Airborne Radiometric Data of the Study Area. 
Field evidence suggests that vein mineralisation in the area are distributed within shear zones traversing biotite gneiss, amphibolite, Schist and at sheared contacts of the Pan-African porphyritic granite [11]. Gold mineralisation is closely connected to hydrothermally altered zones of the bedrock and commonly controlled by both large scale and local structural and tectonic features in southern Ghana [12]. Evidence of alteration that preceded gold mineralisation is best preserved in spatially associated altered mafic dykes and alteration of country rocks occurred under rockdominant, green Schist facies conditions [13]. Therefore, the areas that are hydrothermally altered are potential sites for gold mineralisation. Figure 4 shows the map of the study area depicting the potentially mineralized zones. This is adjudged based on the fact that airborne radiometric surveys may detect potassium enrichment accompanying hydrothermal alteration. This is good indication of a zone that has been potentially mineralized [14]. According to Woakes \& Bafor [1], gold has been geologically associated with the Isanlu Schist belt which encompasses the study area and we already know from literature that gold is brought to the subsurface by hydrothermal processes, so we can therefore infer that the hydrothermally altered zones are possible gold bearing locations.

\section{Conclusions}

The results obtained in this research study have demonstrated that the geophysical tools adopted are powerful and effective means for gold mineral exploration. Hydrothermal alteration zones which are favourable for gold mineralisation have been made possible via the use of aero-geophysical survey method. The areas that are hydrothermally altered are potential sites for gold mineralization, most importantly those areas around Odogbe and Okolom in the north-central portion of the study area. Similarly, regions around Egbe in the western edge are suspected to be mineralized zones. The methods are unique in the sense that they are noninvasive which prevented any environmental degradation. The method enhances the coverage of very large area like that of our Schist belt that covers thousand square kilometres. Moreover, the studies of inaccessible areas that may have posed a problem during data acquisition have been made possible. To the best of my knowledge, this study is the first ever reported research that has employed the use of aeroradiometric survey for gold mineralization in Isanlu Schist belt, North Central Nigeria. This research study is thus novel.

\section{Acknowledgement}

The authors appreciate the help from Nigerian Geological Survey Agency for making the data available for this study.

\section{How to cite this article:}

Ohioma, O., Ezomo, F., \& Akinsunmade, A. (2017). Delineation of Hydrothermally Altered Zones that Favour Gold Mineralization in Isanlu Area, Nigeria Using Aeroradiometric Data. International Annals of Science, 2(1), 20-27.

doi: https://doi.org/10.21467/ias.2.1.20-27

\section{References}

[1] M. Woakes and B. E. Bafor, Primary gold mineralization in Nigeria, 1984, pp. 661-671.

[2] A. G. Onwuemesi, Interpretation of magnetic anomalies from the Anambra Basin of southeastern Nigeria. Ph.D thesis, Nnamdi Azikiwe University, Awka, Nigeria, 1995, pp.74.

[3] C. A. Kogbe, "Review of the basement geology of southwestern Nigeria" in Geology of Nigeria. Elizabethan publishing Company Lagos, 1989, pp. 4158.

[4] N. G. Obaje, Geology and Mineral Resources of Nigeria. Springer, Berlin, Germany, ISBN- 13: 9783540926849 , 2009, pp. 221

[5] T. F. Schwarzer, T. F. and J. A. S. Adams, "Rock and soil discrimination by low altitude airborne gamma-ray spectrometry in Payne County, Oklahoma," Economic Geology, 1973, pp.1297-1312.

[6] J. R. Lundien, "Terrain analysis by electromagnetic means": Laboratory investigations in the 0- to 2.82 $\mathrm{MeV}$ gamma-ray spectral region. U.S. Army Engineers Waterways Experiment Station, Vicksburg, Mississippi, Technical report, 1967, pp. 41

[7] B. L. Dickson and K. M. Scott, "Interpretation of aerial gamma ray surveys-adding the geochemical factors," AGSO Journal of Australian Geology and Geophysics, 1997, 17(2):187-200.

[8] E. Durrance, "Radioactivity in geology": principles and applications. Chichester: Ellis Horwood, 1986, pp. 441.

[9] D. B. Hoover and H. A. Pierce, "Annotated bibliography of gamma-ray methods applied to gold exploration," U.S. Geological Survey Open-file Report, 1990, 90-203, pp. 23.

[10] T. Amenyoh et al., "The use of landsat and Aeromagnetic data," in The Interpretation of Geological Structures in the Nangodi Belt, University of Cape Coast., 2009, pp. 67-77.

[11] S. S. Dada et al., "Structural aspects and history of mineralisation of Isanlu - Egbe tantalite - goldfields, SW Nigeria, Scientia Africana," An Inter. J. Pure and Appl. Sci. 2(1 and 2): 2003, pp. 1 - 16. 
[12] J. Manu, "Gold deposits of Birimian greenstone belts in Ghana": Hydrothermal alteration and thermodynamics, 1993, pp. 83.

[13] A. H. Mumin et al., "Evolution of hydrothermal fluids in the Ashanti Gold belt, Ghana," Stable Isotope Geochemistry of Carbonates, Graphite and Quartz. Economic Geology, 1996, 91(1):135-148.

[14] R. J. Irvine and M. J. Smith, "Geophysical Exploration for epithermal gold deposits," Journal of Geochemical exploration, 1990, vol 316, pp.315-416.
Publish your research article in AIJR journals-

$\checkmark$ Online Submission and Tracking

$\checkmark$ Peer-Reviewed

$\checkmark$ Rapid decision

$\checkmark$ Immediate Publication after acceptance

$\checkmark$ Articles freely available online

$\checkmark$ Retain full copyright of your article.

Submit your article at journals.aijr.in 